\title{
ABDURRAHMAN WAHID, DEPTH ISLAM, AND RELIGIOUS PLURALISM
}

\author{
Media Zainul Bahri
}

State Islamic University Syarif Hidayatullah Jakarta Email: zainul.bahri@uinjkt.ac.id

\begin{abstract}
This essay elucidates the idea of religious pluralism of Abdurrahman Wahid (1940-2009), a very important figure in the tradition of Indonesian Islam. Wahis's ideas of religious pluralism is based on what the so-called "Depth Islam" (DI). DI is different from the usual theological dogmas that only contains concepts and structures. DI is not a literal and superficial forms of religion. It is an understanding that goes beyond the literal texts to look for the principles and spirit of religion in appreciating humanity, diversity and peace. DI may have arisen because of the long process of religious internalization within Wahid experiences, but it is also a hybrid form, i.e., it is a result of the process of encountering or learning Wahid's traditions inter-mingling with cultures of the wider world.
\end{abstract}

Keywords: Abdurrahman Wahid, depth Islam, religious pluralism, interfaith dialogue, Indonesian Islam.

DOI: 


\section{Introduction}

THIS ARTICLE will unravel the idea of Abdurrahman Wahid (1940-2009) on religious pluralism. Wahid, fondly called Gus Dur, became Indonesia's fourth president and was the most prominent Indonesian Muslim leader in the struggle of pluralism for modern Indonesia. It is an interesting fact when we consider that Wahid was born and raised in an environment of strong traditionalism, namely Nahdlatul Ulama (NU) and is genealogically connected to the Wali Songo (the Nine Saints) of Islam in Java, mainly Sunan Ampel, whose lineage leads to the Prophet Muhammad, but he surpassed his own traditional base. In addition to the fact that Wahid came from an aristocratic family, he also befriends with leaders of various religions here and overseas. Friends of Wahid such as Ibu Gedong Bagus Oka, Romo Mangun, Pramudya Ananta Toer, Franz Magnis Suseno, Dalai Lama, Daisaku Ikeda, Kim Dae Jung, Sulaksiwaraksa, Bill Clinton, Swami Shanti Prakash, and many others showed his extensive networks and in-depth exchange of ideas. Dealing with Jewish community, while studying in Iraq (1966-1970), Wahid made an unusual friendship with Ramin, a Jew from the small Iraqi Jewish community and learned Judaism from him for some years. During his tenure as general chairman of NU, Wahid also had close relations with Israeli Jewish leaders and interestingly, was appointed as one of the board members of the Institute of Simon Peres (1997). In 2007, Wahid also received the Medal of Valor, Bravery Medal, from Simon Wiesenthal Center, Los Angeles-United States, because of his courage in defending peace and pluralism in Indonesia.

The idea of religious tolerance and pluralism promoted by Wahid, born out of deep appreciation of his own religion, is extremely relevant to re-discuss amid the rampant "theology of anger and hatred" that threatens diversity and humanity in Indonesia today. It is very important to show the originality and depth aspects existing in Indonesian Islam confessed by Wahid, instead of settling for a literal and superficial Islam. 


\section{Attitudes toward Other Religions}

Dealing with religious diversity and beliefs, some scholars of religious studies-especially in the Christian world, have formulated a typology of religious attitudes. The most famous models are exclusivism, inclusivism and pluralism. Exclusivism means "there is only one true religion." Exclusivism states that one's own community, tradition, and encounter with God comprise the one and only exclusive truth; all other claims on encountering God are, a priori, false. Inclusivism means "one religion is best but weaker forms of religion are possible in other religions." Inclusivism states that one's own religion possesses the truth; other religious groups contain parts of the truth. So, one's own religion remains the best. ${ }^{1}$ Pluralism means "other religions are equally valid ways to the Same Truth," or "other religions speak of different but equally valid truth," or "many ways to God," or "all paths lead to the same summit." According to Brill, religious pluralism stressed that no one tradition can claim to possess the singular truth. All groups' beliefs and practices are equally valid, when interpreted within their own culture. Thus, no one religion is inherently better or superior to any other major world religion. For pluralists, there may be differences in rituals and beliefs among these groups, but on the most important issues, there is great similarity. ${ }^{3}$

According to Brill, there are three main types of pluralism: epistemological, ethical, and mystical. The first type sees that there are limits to human knowledge. Therefore, one has to accept reality of the truth of all religions. The ethical category

${ }^{1}$ Alan Brill, Judaism and Other Religions: Models of Understanding (New York, USA: Palgrave MacMillan, 2010), 16.

2On those adagium (maxims) see Paul F. Knitter, No Other Names? A Critical Survey of Christian Attitudes toward the World Religions (New York: Orbis Books, 1985); One Earth Many Religions: Multifaith Dialogue and Global Responsibility (New York: Orbis Books, 1985); Introducing Theologies of Religions (New York: Orbis Books, 2003); The Myth of Religious Superiority, Multifaith Explorations of Religious Pluralism (New York: Orbis Books, 2005). See also Seyyed Hossein Nasr, Knowledge and the Sacred (Albany, New York: State University of New York Press, 1989) and John Lyden (ed.), Enduring Issues in Religion (San Diego, USA: Greenhaven Press, 1995).

${ }^{3}$ Brill, Judaism, 16. 
sees that all ethical people are on the right path. The mystical type envisions that the encounter with God transcends any human categories. There are also two terms that are used often by twenty-first century pluralists: difference and diversity. The term of "difference" is the acknowledgment of many different approaches to religion, each to be tolerated and accepted without discrimination, while "diversity" is the acknowledgment that the many different approaches to religion are each valuable and desired for the diversity of human life. ${ }^{4}$

In addition to the above three models, Brill added a fourth model: universalism or "the truth is one". This model is midpoint between inclusivism and pluralism, where one acknowledges that the universal truths of God, soul, intellect, and ethics have been made available by God to all people. ${ }^{5}$

Ninian Smart, a prominent scholar on religious studies, categorizes five typologies of religious attitudes. First, absolute exclusivism. Second, absolute relativism. For Smart, the various religious system cannot be compared with each other because one has to engage into an insider to understand the truth. Third, hegemonic inclusivism. Forth, realistic pluralism. Fifth, regulatory pluralism means all religions have the values and beliefs of each experiencing a historical evolution and progress towards the same truth. However, the same truth has not been defined. ${ }^{6}$ In Christianity, there are critical views of Hans Küng and Paul Knitter. Küng, an influential Christian scholar called the four responses to religious diversity. First, atheistic view that sees no one religion is true. Second, there is only one true religion and others are false (exclusive). Third, all religions are true (pluralist). Forth, one's own religion possesses the truth; other religious groups contain parts of the truth. ${ }^{7}$ Knitter calls the four models of religious attitudes within the Christian world. First, the replacement model: "only one true religion." Second, the fulfillment model: the one fulfills the many." Third, the mutuality

4Ibid., 30 .

5Ibid., 17.

'Hendar Riyadi, Melampaui Pluralisme: Etika al-Quran tentang Keragaman Agama (Jakarta: RMBooks\& PSAP, 2007), 86.

7Ibid., 87. 
model: many true religions called to be dialogue." Forth, the acceptance model: many true religions, so be it." ${ }^{8}$

Komaruddin Hidayat, Indonesia's leading Muslim scholars, called five typologies. First, exclusivism. Second, inclusivism.Third, pluralism. Fourth, eclecticism. For Hidayat, this model means the religious attitude of one whom trying to select and to find command words of various aspects of religious teachings that are considered good and suit for him so that the final format is a religious mosaic that is eclectic. Fifth, universalism, the religious attitude sees that basically all religions are one and the same. Only because of the historical-anthropological, religion then appears in the plural form. ${ }^{9}$

In general, the various models above are formulated by leading scholars actually pursed into three well-known models: exclusivism, inclusivism, and pluralism. Now we will try to situate Wahid's theological views related to diversity of religions.

\section{Theological and Political Views}

Almost all Indonesian religious scholars agree that it is impossible to deliberate a discourse of religious pluralism in Indonesia without mentioning Abdurrahman Wahid. Many refer to him as father of modern Indonesia pluralism. He himself apparently, would rather be more pleased to be remembered as a humanist. His youngest daughter, Inayah Wulandari, plead that his tomb be written "Here buried is a humanist." According to Inayah, throughout his life Wahid championed humanity, instead of pluralism. She asserts that "When Wahid (desperately) defended the Chinese, Ahmadis, Christians and other marginalized peoples, what Wahid pursued was not based on their Chinese-ness, their Ahmadism, nor their Christianity, but humanity. Therefore, he is more rightly called a humanist." Inayah's statement is accurate if we look closely at Wahid as a genuine believer and an active cultural figure. Religion and culture were consolidated in his being and were

8 Knitter, Introducing, vii-ix.

${ }^{9}$ Riyadi, Melampani, 87.

10Inayah Wahid, "Wahid Bukan Tokoh Pluralisme," Tribunnews October 16, 2012. 
expressed in the humanism and pluralism of his thoughts, speech and action, his humanist vision in correlation to his pluralist attitude.

Wahid, to my knowledge, did not write much about theological arguments on religious pluralism, although penned hundreds of articles since the 1970s, printed in opinion columns of various Indonesian media, gave a myriad of interviews and wrote dozens of papers with a variety of themes, including the idea of humanism, universalism, inclusivism and religious pluralism. Wahid's existing books usually contain a compilation of his articles or presented papers. To facilitate this article however, let us follow his work systematically. Wahid's idea of pluralism, especially those widely publicized in the early 1980s to late 2000s, is rooted in two main points: first, the theological view, in terms of theology as a product of cultural struggle, and second, the political view. Let us then look at these two things.

Wahid had once said, and this was quoted by Muhammad Ali, that religious pluralism is a new concept (in Islam) not discussed in the scholarly works of classical and medieval Muslims. However, this does not mean that in itself the character of Islam is not pluralist. ${ }^{11}$ Due to non-explicit theological discussions in classical books, Wahid placed his views on the universalism of Islam into writing. According to him, Islamic universalism manifests itself in various prominent manifestations of its teachings. Islamic sciences such as tawhid, fiqh, and ethics (akbläq) display a very large concern to the main elements of humanity (al-insaniyyab). Further, that there are fundamental principles that support humanity such as equality before the law, protection of citizens from tyranny and despotism, protecting the rights of the weak and those suffering from shortages, besides restriction on the authority of those in

${ }^{11}$ Muhammad Ali, "Wahid as a Defender of Pluralism and Religious Freedom," The Jakarta Post, January 6, 2010. Muhammad Ali is Associate Profesor at the Department of Religious Studies, University of California. Ali wrote his thesis on Wahid's political and religious thoughts. 
power. ${ }^{12}$ One of the principal characters of Islamic universalism as a revelation of God is the doctrine of ușul al-khamsah (five principles), which warrants humane acts. Ușīl al-khamsah is scattered in the literature of Islamic jurisprudence ( iqh). One of the main securities given is the safety of people in their religious belief, without any compulsion of conversion to Islam. ${ }^{13}$

Insights into Islamic universalism begun with the contact of Islamic civilizations with other cultures, and is familiarly termed "Islamic cosmopolitanism." The nature of Islamic cosmopolitanism according to Wahid existed in truth since the early days of Islam. ${ }^{14}$ The prophet Muhammad for example took cultural wisdom from non-Arabic countries, such as India or China, as a practical enrichment to his life, and acknowledged this in parts of the sunnah, e.g. the tradition of cupping therapy, which the Prophet learned from India.

The Prophet also studied and took in other cultures during the Madina period. The cosmopolitanism process continued until the advent of early Muslim lexicographers (such as al-Jạhiz) in the third century Hijriyah. Within this period, Islam and other civilizations around the Islamic world went through a time of mutual cultural absorption, also taking in cultural remnants of the ancient Greek civilization of Hellenism up to the civilization of the Indian subcontinent. ${ }^{15}$

In this spirit, according to Wahid, the first Muslim zähid or ascetic expanded the Islamic civilization. Imām Hasan al-Bașri, for example, was known not merely asan excellent Sufi, but also as a linguist. Imām al-Khāil Ibn Aḥmad al-Farāḥici, a philologist who studied the Qur'an closely, was also known for his exceptional piety, and was evidently a fan of ancient Greek philosophy. ${ }^{16}$ This could be seen from his great work, Qämùs al'Ayn, which fully utilizes the knowledge of division through the

12Abdurrahman Wahid, "Universalisme Islam dan Kosmopolitanisme Peradaban Islam," in Kontekstualisasi Doktrin Islam dalam Sejarah, ed. Budhy Munawar-Rachman (Jakarta: Yayasan Paramadina, 1995), 545.

13Ibid., 546.

14Ibid., 545.

15Ibid., 549.

16Ibid., 551. 
categorization of Greek philosophy. Not to mention Ilm alKalam (Islamic Theology), Islamic Philosophy, and Islamic Sufism which also absorbed many elements of Greek Philosophy: Platonism, Neo-Platonism, and the Aristotelesism.

Cosmopolitanism in the Islamic civilization, in Wahid's view, appeared in a number of dominant elements, such as the disappearance of ethnic boundaries, the strength of cultural plurality and political heterogeneity. Cosmopolitanism also appears as a stunning and dominant element in centuries of eclectic religious life. According to Wahid, the heated debate which arose among Muslim scholars groups, for example between the Mu'tazili with Ash'ari and his disciples, could not merely be seen as a crisis of religious Muslim life due to the lack of consensus on the fundamentals, but can also be read as a form of freedom of thought and creative dialogue between them. ${ }^{17}$ Wahid maintained, that the optimal point of cosmopolitanism in Islamic civilization was only achieved, when the balance between normative tendencies of Muslims and freedom of thought to all citizens (including non-Muslims) was reached. He viewed as creative cosmopolitanism, because its citizens took the initiative to seek insight, instead of merely to holding on to a given truth. This creative and fluid situation, which allowed the search to find other truths had also forced teachings of Islamic universalism to continually manifest themselves in tangible forms, in contrary to evident speculative postulates. ${ }^{18}$

This cosmopolitan character was, however, lost when certain Muslim communities started prohibiting scientific debate, and then both judged and sentenced those they deemed "deviant," while continuing to proclaim their own particular theological doctrines (such as al-Ash'ari or Ahl al-Sunnah) as the single truth of Islam. ${ }^{19}$ This claim of a single truth is a major and heartbreaking tragedy for the Islamic world.

The history of Islamic cosmopolitanism is one of the most significant factors that "matured" the soul of Wahid's humanism

17Ibid., 549.

18Ibid., 550.

${ }^{19}$ Ibid. 
and pluralism. Thoughts on this are visible in Wahid's first publication, Muslim di Tengah Pergumulan (1981). One of points of this publication is "the necessity for openness in exploring various ways of thinking and the willingness to seek truth, no matter where it is." 20 In a different article, Wahid states that Islam does not believe in humiliating other civilizations and that to push its development, teaches to seek and learn from advances in other civilizations. To achieve excellence, the Prophet said "seek knowledge to the land of China." Through this hadith, the Prophet advocated Muslims to seek excellence in cultures anywhere. This, according to Wahid, meant that religious people should not be prejudiced against anyone, because science and technology are now spread everywhere. ${ }^{21}$

In an article titled Kasidah (1982), Wahid talked about Islamic music. He posed the question of which type of music represented Islam in Indonesia: the Arab form of Gambus or modern kasidah music? On this, Wahid consulted his friend, a cultural figure who taught a music class, and was interested in painting and languages. The friend replied, "Music is universal, it can be recognized anywhere. Pop and classical music containing religious messages of high quality will be appreciated everywhere." Wahid himself is very fond of classical music. For him, the natural softness and originality of Beethoven's Pastoral Symphony for example, can deliver listeners to the grandeur of nature, and of course ultimately to the Creator of nature itself. Wahid felt that classical music strengthens the belief in the majesty and greatness of God. That is why he did not wish to be separated from the works of Beethoven and Johann Sebastian Bach. ${ }^{22}$ With this insight, the so-called "Islamic" for Wahid is the spirit, the substantial, not the form or its label.

\footnotetext{
${ }^{20}$ Abdurrahman Wahid, Muslim di Tengah Pergumulan (Jakarta: Leppenas, 1981), 3.

${ }^{21}$ Abdurrahman Wahid, "Dicari: Keunggulan Budaya," Duta Masyarakat, July 5, 2003. See also Wahid, Islamku, Islam Anda, Islam Kita: Agama Masyarakat Negara Demokrasi (Jakarta: The Wahid Institute, 2006), 266.

${ }^{22}$ Abduurahman Wahid, "Kasidah", in Melawan dengan Lelucon: Kumpulan Kolom Abdurrahman Wabid di Tempo, ed. Mustafa Ismail (Jakarta: Tempo, 2000), 249-250.
} 
If truth can be found everywhere and in any civilization, in the sense that it is not automatically and entirely provided by Islam, then what does the statement that 'Islam is a perfect religion' as stated in Qs. al-Ma'idah: 3.23 According to Wahid, many Muslims view that this statement as meaning that Islam is complete in every sense, hence not needing any outside input. Wahid finds this to be a weak point of view, since in fact the word of God in al-Ma'idah verses states that Islam does not prohibit the continuous development of new insights. The nature of Islam's perfection and completeness, according to Wahid, is precisely its potential to accommodate for continuous inputs, as part of the claim of facing a process conditional to its era, and not solely the detailed terms of which it is designated to. Islam does not prescribe verbatim to every problem of life, but rather expresses substance. Its substance is the openness to other thoughts. Wahid stresses that the latter view is derived from and even encouraged by the Qur'an itself. ${ }^{24}$

If Wahid was asked, what theological arguments can be conceived as supporting the idea of religious pluralism are, one of his answers would be to quote verse 13 of al-Hujurāt: "O men! Behold, We have created you all out of a male and female, and have made you into nations and tribes, so that you might come to know one another (li ta'árafü)." 25 "To know one another" for Wahid means, not only to know the person's name and home address, but more importantly to understand the habits, traditions, customs, thoughts, and desires, which may different from what one is be accustomed to. Moreover, the verse li ta'arafü means that "each of you be wise for others." In continuation of the verse, it is stated: "Verily, the noblest of you in the sight of God is the one who is most deeply conscious of

23The verse sounds, "Today have I perfected your religious law for you, and have bestowed upon you the full measure of My blessings, and willed that self-surrender unto Me shall be your religion." See Muhammad Asad, The Message of The Qur'an (Gibraltar: Dar al-Andalus, 15 th Hijriyya), 141.

${ }^{24}$ Abdurrahman Wahid, "Beberapa Aspek Teoritis dari Pemikiran Politik dan Negara Islam," Aula, no. 1 (1987): 47.

${ }^{25}$ Asad, The Message, 794. See Abdurrahman Wahid, "Lain Zaman, Lain Pendekatan", in Kala Fatwa Jadi Penjara, ed. Ahmad Suaedy (Jakarta: The Wahid Institute, 2006), xxviii. 
Him (atqākum)." ${ }^{26}$ Taqwā (conscious of God), for Wahid, is not merely having personal piety, but more importantly to show social piety, which is full of love for humanity.

Wahid is most known for his "love and respect for human dignity." Musthafa Bisri, a prominent NU member and a close friend to Wahid, often witnessed Wahid defending oppressed or minority groups without minding their religious or cultural background. In a conversation about it, Wahid stressed that it is in accordance with the teachings of the Quran and quoted the Qs. al-Isrā': 70: "Now, indeed, We have conferred dignity on the children of Adam..."27 ("walaqad karramnā bani Adam..."). Wahid then continued by asking, "God glorifies humanity, so why do we not follow God's glorious character?" Bisri was often moved by Wahid, who often appeared to "stand alone" in defense of humanity. Bisri maintained that God accompanies the lone person doing noble deeds and concluded that God loves Wahid. ${ }^{28}$

Expanding on the discussion of humanity, Wahid explained the criteria for taqwa with reference to the al-Baqarah, verse 177. The first part of this verse says, "True piety does not consist in turning your face towards the east or the west; but truly pious is he who believes in God and the Last Day and the angels and revelation and the prophets." 29 According to Wahid, this is a fragment of the five pillars of faith. In the Sunni creed, it is supplemented with faith in qad $\bar{a}$ (fate) and qadar (determination). After which, it is stated in the middle phrase of the verse: "and spends his substance-however much he himself may cherish it - upon his near of kin, and the orphans, and the needy, and the wayfarer, and the beggars, and for the freeing of human beings from bondage." 30 According to Wahid, the second phrase is longer than the first one. Then, the next verse said, "...and is

26Husein Muhammad, "Pluralisme Wahid, Gagasan Para Sufi," Cabaya Sufi, 2010, 102-103.

${ }^{27}$ Asad, The Message, 428.

${ }^{28}$ Bisri delivered it in 1000 days commemoration of Wahid death (baul) at Ciganjur, Jakarta in December 2012.

29See Asad, The Message..., 36.

30Ibid. 
constant in prayer, and renders the purifying dues; and (truly pious are) they who keep their promises whenever they promise, and are patient in misfortune and hardship and in time of peril: it is they that have proved themselves true, and it is they, they who are conscious of God." 31 Wahid asserts that this third phrase is the Pillar of Islam. ${ }^{32}$

He further contended that the second fragment is in fact a social ethos and pronouncedly universal, and therefore could only be designated as an Islamic Social Pillar (RukunTetangga Islam). However Wahid maintains that this Pillar in Islam is precisely the most inspiring, because it is not normative and no longer questions any limitation. It is a global norm, the necessity to do good for other people and trying to improve other people's lives. In other words, this Rukun Tetangga is a pillar of humanity; the ethic of human love which disregards religious cloth, creed, class, tribe, and nation, an attitude that throughout his life Wahid consistently showed. Due to its global and unlimited nature, this pillar of humanity is not comparable to any pillar of faith or any pillar of Islam. For Wahid, although people may appear to have faith because they are seen as practicing the creed of their beliefs, they may not necessarily be righteous (taqwa) if they do not fulfill the social and humanitarian ethos. ${ }^{33}$

Here, we see Wahid as a cosmopolitan universalist and humanist. Wahid's proximity to the world of mysticism (Islamic sufism) is common knowledge. As someone who was born and grew up in a very traditional environment (Nabdlatul Ulama), Wahid was particularly fond of things irrational, as seen in his penchant to make pilgrimage to the wali (saint) tombs. During his time as Chairman of NU, according to Cholil Bisri of Rembang, each time an important decision had to be made, Wahid preferred to visit the wali tomb, rather than consult with the elderly clerics (kyai sepub). Of course, many NU Kyais

${ }^{31}$ Ibid.

32Abdurrahman Wahid, "Peranan Umat dalam Berbagai Pendekatan," in Kontroversi Pemikiran Islam di Indonesia, ed. LPPM (Bandung: Remaja Rosdakarya, 1990), 199-201.

33Ibid. 
objected to Wahid's attitude. However, Wahid was familiar with these objections and often answered tongue-in-cheek: "I go to the tomb because I do not believe in the living. The dead had no interest anymore." 34 The tradition of honor and trust among friends of God, and between those who are still alive and ones who have passed away is a tradition that has for centuries been firmly rooted in the world of Islamic Sufism. Similar to Wahid, Shaykh al-Akbar Ibn 'Arabi, for example, is one that is also very fond of Sufistic pilgrimage to the tombs of saints, and claims that he often has dialogues with their spirits. ${ }^{35}$ About Wahid's connection to the mystical world, Greg Barton states that "Wahid grew up in an enchanted universe in which the spiritual was as real as the material." 36

Wahid's mystical world here is important because it relates to his view of pluralism. This Sufist insight stands out in many ways. Wahid's other (mystical) worldliness may be seen as helping him appreciate other non-Islamic beliefs. Wahid had very close relationships with many religious leaders, including the Catholic priest Romo Mangun, Ibu Gedong Bagus Oka, a leader of Balinese Hinduism and Ajarn Sulaksivaraksa, a Buddhist monk from Thailand. According to Wahid, his close friendship with Ibu Gedong and Romo Mangun is not only due to the view that friendship should not be based on religion, but also because of the belief that all true religions serve the same substances of God. Wahid emphasized that God, in His essence is the same for each religion. Only the concept and attributes are different. ${ }^{37}$

In a discussion over the concept of wali (saint) in various religious traditions, Wahid came to the conclusion there exists a similar meaning to wali: apart from the distinguishing properties

${ }^{34}$ Hamid Basyaib and Fajar Hermawan (eds.), Ger-Geran Bersama Gus Dur: Edisi Spesial Mengenang Gus Dur (Jakarta: Penerbit Nawas, 2010), 180181.

${ }^{35}$ Concerning a close relationship between Ibn Arabī and his masters, see RWJ Austin, Sufis of Andalusia (London: George Allen \&Unwin, 1971).

${ }^{36} \mathrm{Greg}$ Barton, Gus Dur: The Authorized Biography of Abdurrabman Wabid (Jakarta-Singapore: Equinox Publishing, 2002), 120.

${ }^{37}$ Moh. Shaleh Isre (ed.), Tabayun Gus Dur, Pribumisasi Islam, Hak Minoritas, Reformasi Kultural (Yogyakarta: LKIS, 1998), 116. 
as holy men, as God's gift, a wali is also someone who sacrifices his or her life for the benefit of humanity. The three, Ibu Gedong, Romo Mangun, and Wahid agreed that all walis lived to serve humanity. Only the term differs, each respectively using sanskrit (rsi, Hindu), Latin (saint or santo, Catholic) and the other in Arabic (wali, Islamic). Wahid finds that by looking at essential similarities in the varying religions, there are more elements that unite rather than separates, and these uniting factors should promote an attitude of mutual respect for each other. ${ }^{38}$

For Wahid, all religions are essentially the same as they are revealed from the same God. Wahid's view is the same as the doctrine of perennial philosophy, that the one essence is manifest in many attributes, forms and various cultural identities. Differences in shape or in religious manifestations caused by cultural diversity according to Wahid, should actually make people get to know and love for the sake of morality, solidarity, and compassion towards each other. ${ }^{39}$ Wahid's esoteric religious outlook led him to Islamic interpretations which are liberal and pluralist; liberal in the sense that his religious' views went beyond the texts. Discourse on an infidel or kafir For Wahid, non-Muslims who have faith cannot be called käfir. In Wahid's interpretation, the infidels spoken of in the Qur'an are people who deny the existence of God, God's grace, and within the context of that time, those who fought the Prophet Muhammad and his companions in Mecca. Wahid believes the matter should be understood contextually. ${ }^{40}$

On Muslims who celebrate Christmas or participate in the activities of their Christian neighbors, Wahid prescribes to the view that Jesus had a special place in Islam. He states that "If we fully follow the teachings of our religion, then we (Muslims) can also celebrate Christmas as we celebrate the birth of Prophet

${ }^{38}$ Abdurrahman Wahid, "Perjalanan Romo yang Bijak," Harian Kompas, February 11, 1999.

${ }^{39}$ Muhammad Ali, "Wahid as a Defender of Pluralism", The Jakarta Post, January 6, 2010.

40 Ibid. In one interview with Radio $68 \mathrm{H}$, Wahid reiterated that the only intended as infidels in the Qur'an is the Pagans (polytheists) of Mecca, while Jews and Christians more appropriately classified as Ablal-Kitäb (the People of Book). 
Muhammad."41 In his article Harlah, Natal dan Mawlid (2009), Wahid reiterated that Christmas was recognized by the holy book of the Qur'an. Hence, there is a pointer to the birth of the Prophet Isa, which should also be respected by Muslims. For Wahid, celebration of Christmas as a form of homage to the Prophet Isa--in his belief as a prophet of God--or whether the birth is then celebrated in a different manner, or a similar form but with a different intent, need not be questioned. Muslims are free to participate in honoring the birth of Christ, or the socalled Christmas Day. They are free to celebrate it or not, because it is allowed by Islam. Wahid himself respected Jesus and was happy to celebrate it with Christians. For Wahid, "Respect for the non-Muslims by Muslims, by no means indicate that we have left our own faith, but it shows the maturity of our views in their eyes." 42 In Egypt for example, according to Wahid, Muslim mufti, who are not government officials, send Christmas greetings in writing to Pope Shanuda (Pope of the Coptic Christians in Egypt), vice versa the Pope also congratulates Muslims on Eid al-Fitr and Eid al-Adha. For Wahid, Christmas and the birth of Prophet Muhammad, originally a religious event eventually became a "cultural" practice, as it was "acculturated" by the local commune. ${ }^{43}$

Wahid views which are religious, humanist, and pluralist, according to the pluralist Husein Muhammad, a prominent NU supporter from Cirebon, are also professed by great Sufis such as Ibn 'Arabi, Rūmì, al-Ghazāil, and Ibn'Ațāillah, citing that they often voice the idea of pluralism and universal brotherhood. They believe there is nothing in the universe except the one God and all that exists are submissive and surrender before Him (God). This means that those in existence have always and will

41Zainul Fuad, Religious Pluralism in Indonesia: Muslim-Christian Discourse (Hamburg: Hamburg University, 2007), 136.

${ }^{42}$ Abdurrahman Wahid, "Kebenaran dan Penolakan Atasnya," in Kala Fatwa Jadi Penjara, ed. Ahmad Suaedy (Jakarta: The Wahid Institute, 2006), 120.

${ }^{43}$ Abdurrahman Wahid, "Harlah, Natal, dan Maulid," www.gusdur.net, December 23, 2011. 
continue to seek Him (God) through different roads and languages. Here a quotation of a beautiful sufi poem:

Our language is so diverse

But thou art the only Beautiful

And each of us headed

The beauty of the One ${ }^{44}$

\section{Pancasila, Islam, and Pluralism}

Wahid's views were also rooted in his political stand, i.e. he was a nationalist. He believed that the five pillar philosophy of Pancasila was more suitable for Indonesia, than the ideology of an Islamic state. Pancasila, which serves as the foundation of the state ideology and constitution, accommodates the aspirations of various religions and guarantees all religions the same rights and responsibilities before the law. Although incomparable to religion, Wahid understood Pancasila as the rules that govern all religions and beliefs of the Indonesian.

As a nationalist, Wahid maintained that the nation founders were precautious in placing Pancasila as the state foundation. He also often referred to the support that Islamic leaders later gave the nation founders, pointing out that the NU Congress (1935) in Banjarmasin (South Borneo) at first decided that the Dutch Indies state once ruled by the Dutch (non-Muslims) should maintain religious obligation for two reasons: first, because Muslims would be free and independent in carrying out Islamic teaching, and second, because the archipelago (Nusantara) formerly had Islamic Kingdoms. ${ }^{45}$ Later, the flexibility of NU and other Islamic leaders was demonstrated through their acceptance of Pancasila and the 1945 Constitution as the state's basis, while rejecting the Jakarta Charter, a second formulation of the Pancasila which obligated Muslim adherence to the Islamic Sharia.

44Husein, "Pluralisme," 106-108.

${ }^{45}$ Abdurrahman Wahid, "Islam, Ideologi dan Etos Kerja di Indonesia", in Kontekstualisasi, ed. Munawar-Rahman, 582. See also Wahid, Islamku, 101. Wahid himself refers to Einar Martahan Sitompul's Magister thesis entitled, NU dan Pancasila: Sejarah dan Peranan NU dalam Perjuangan Umat Islam di Indonesia dalam rangka Penerimaan Pancasila sebagai Satu-Satunya Asas (Jakarta: Sinar Harapan, 1989). This work provided a foreword by Wahid. 
However, Wahid explained that process of adaptation between Islam and Pancasila is not complete, considering the recurring friction between Muslims with the state interests, which arises owing to differences in character of the two. Islam, as a religion, imposes normative values on the individual and collective lives of its adherents, while states like the Republic of Indonesia are not likely to impose normative values on all its citizens, which are not accepted or derived from different religions existing in the country. In other words, not all the values held normative by Islam, may be enforced in civic life of Indonesia. ${ }^{46}$

The acceptance of the Pancasila ideology by Muslims is properly seated, i.e. as the constitutional basis for the life of the nation, while Islam became the creed in the life of Muslims. As the constitutional basis, Pancasila is neither opposed to religion, nor looking to replace and be treated as a religion. ${ }^{47}$ For Wahid, the essence of Pancasila is to maintain pluralism. Wahid refers to President Sukarno's speech, where diversity is stated as the reason (raison d'etre) for founding the nation. Diversity or plurality of the nation's culture, besides binding the nation together, also provides the richness contained in what was to be called the Republic of Indonesia. ${ }^{4}$ Pancasila, which is based on this diversity, therefore guarantees all religions freedom of belief and the freedom of all people to express their beliefs.

This is why for Wahid, curbing freedom of religion for any reason, including the state, is a criminal act that should be resisted. ${ }^{49}$ According to Wahid, awareness of pluralism would only appear if the state does not prescribe "formalization" of religious teachings. In Wahid's theological understanding, as the Qur'an itself guarantees freedom of religion, the state should not determine one particular religion more superior than

46Wahid, "Islam”, 583.

47Ibid., 585.

48Abdurrahman Wahid, "Haruskah Inul Diberangus?" Memorandum, May 10, 2003.

${ }^{49}$ Agus Hadi Nahrowi, "Religious Pluralism In Indonesia: Helpful and Hindering Aspects," Issuelab, August, $10 \quad$ (2006). http://www.issuelab.org/organizations/profile/pluralism_project accessed 
another. ${ }^{50}$ However, within the context of Indonesia's religious communities' Wahid does not agree that Pancasila means giving away to secular ideology, in the sense of separating religion from the state such as the view of the Egyptian liberal thinker $\mathrm{A} \Gamma$ 'Abd al-Rāziq on secularism. Religion, in this case Islam, according to Wahid, in the Pancasila state has two functions: firstly, as a source of social ethic, and secondly, that Islamic elements could actually penetrate into positive law through consensus, such as the birth of the laws concerning marriage (1974) and Act of Religious Courts (1989) ${ }^{51}$ as a product in accordance with "the spirit of Islam."

In the context of Pancasila and the value of diversity and freedom of religion, Wahid is always at the forefront in defending minority groups whose religious freedom are inhibited by the majority group in Indonesia. Wahid's defense of religious freedom, whereby he criticizes the views and attitudes of Muslim groups and leaders, such as the Indonesian Ulama Council (MUI) who he admonishes for being arrogant in their fatwas, especially concerning the prohibition of pluralism and Ahmadiyah "heresy." According to Wahid, boundaries and relationships between the truths of belief among religious association in the context of the Republic of Indonesia cannot only be viewed from the framework of religious belief alone. Countless Muslim see and treat followers of other religions only within Islamic theology course framework. In using this as the sole measurement, a Muslim becomes very arrogant and complacent when he or she 'defeats' another religion. Such arrogance is what makes many Muslims "narrow viewed" and guilty of practicing double standards in their participation in the nation state. On the one hand, to stay alive, they need the state. On the other hand, they do not care about the existence of the state. In fact, the only one way to defend Islam in Indonesia is to understand the character of the country's ideal of religious pluralism, which calls for tolerance of one another' belief. In this sense, Wahid views the MUI fatwa on the unlawfulness of pluralism shows an attitude of disregard towards the core of

${ }^{50} \mathrm{Ali}$, "Wahid" (2010).
${ }^{51}$ Wahid, "Islam", 585. 
religious life in this completely plural country. That is why the founders of the Indonesian Republic insisted that the state not be a religious state. Otherwise one is stuck with the question of whether Muslim leaders of the founding era, such as Ki Bagus Hadikusumo and Kahar Muzakir of Muhammadiyah, Abikusno Tjokrosuyoso of Sharikat Islam, Achmad Subarjo of Masjumi, AR. Baswedan from the Indonesian Arab Party, KH Wahid Hasjim of Nahdlatul Ulama and H. Agus Salim, were bogus leaders who do not represent Islamic groups ?52

According to Wahid, these Muslim founders of Indonesia had a broader view regarding the reciprocal relationship between followers and leaders of differing religions. For more than four decades, religious traditions lived in mutual respect. Rhetorically Wahid asked: "Why must we accept the "rigid views" perpetrated by a handful of people who 'use' the MUI improperly? Is that not a hasty attitude of those who regard themselves as the party who is entitled to interpret the 'truth' of Islam?53 When Mr. AA Maramis appealed against the Jakarta Charter because it would lead to the emergence of two classes of citizens in Indonesia (Muslims as first-class and non-Muslims as second class citizens), Wahid reiterated that the promoters of a religious state, then agreed entirely with dispensing the charter from the opening of the UUD 45. This means that this nation was no longer a religious state or to be precise, Islam is not the religion of the state and thus the interpretation of the Supreme Court on the UUD 45 being the only legal interpretation of the law in this country. ${ }^{54}$

A very important aspect of Wahid's thoughts on Islam, the state and pluralism is his rejection of the formalization, ideological and shariatization of Islam. ${ }^{55}$ For Wahid, the glory of Islam lies in its ability to thrive culturally. ${ }^{56}$ In other words,

52Wahid, “Kebenaran”, 120.

53Ibid., 121.

${ }^{54}$ But now the Constitutional Court $(\mathrm{MK})$ was the highest legal institution.

55M. Syafi'i Anwar, "Islamku, Islam Anda, Islam Kita, Membingkai Potret Pemikiran Politik KH Abdurrahman Wahid," in Wahid, Islamku, xv and, 24.

${ }^{56}$ Ibid., 40-41. 
Wahid appreciates the effort of culturalization. Hence, the verse sounds "udkhulu fi al-silm kaffah" where al-silm is interpreted by the formalists with the word "Islamic," is interpreted by Wahid as "peace." According to Wahid, the consequences of the two interpretations have broad implications. Those who are accustomed to formalization will be tied to the efforts for the realization of the "Islamic system" which is fundamentally ignoring the plurality of society. Additionally, people who disagree with the interpretation "Islamic" will be considered less or un-Islamic. "Islamic system" will also automatically put nonMuslims below the position of Muslims, or in other words, nonMuslims would become second-class citizens. ${ }^{57}$ Wahid explicitly rejects this.

Wahid also resisted Islam as an ideology, because it does not conform to the development of Islam in Indonesia, known as the "moderate Muslim country." Islam in Indonesia, for Wahid, appeared in everyday life and culture, not ideologically clad. ${ }^{58}$ On the other hand, Wahid saw that Islamic ideology easily encourages Muslims to political attempts that lead to a radical interpretation of religious texts. The most obvious implication of Islamic ideology can be seen among the number of efforts to make Islam an alternative ideology to Pancasila, as well as the few groups desiring to fight for the return of the Jakarta Charter. Besides this, there are a number of local governments and the parliaments that passed laws based on "Sharia Islam." According to Wahid, the efforts to "go-Islamize" the state and "goshariatize" by-laws are not only a-historical, but are also contrary to the 1945 Constitution. ${ }^{59}$ As is so often declared, Wahid explicitly rejects the idea of an Islamic state. ${ }^{60}$ His attitude is based on the view that Islam as a way of life does not have a standard concept of the state. ${ }^{61}$ Wahid claimed that all his life he had searched in vain for a "creature" called the Islamic state. He stated: "To this very day, I have not found it. Hence, I came to

57Ibid., 3-4.

58Ibid., 60.

59Anwar, “Islamku...”, xvi. Ibid., 81, 89-91.

${ }^{60}$ Ibid., 50-51.

61Ibid., 113-115. 
the conclusion that Islam does not have that concept of how the state is created and maintained." 62

According to Wahid, the strengthening of Islamic fundamentalism in the last two decades has brought about arrogant Islamist groups who wish to show the superiority of Islam over other religions. Members of these groups are those without a profound knowledge of religion. They take pleasure in being excessively suspicious and prefer to accentuate existing differences, rather than seek the intersections of similarities between Islam and other religions. This situation can actually divide the Muslims themselves. Therefore according to Wahid, besides re-impregnating the theological view of the Qur`an, that human beings are created different to each other, Muslims must also be realistic and aware that they are not alone, but that God destined them to live together with people of other faith, even with atheists, or those, who have other ethical frameworks. ${ }^{63}$ Muslims can live together with other people in a bond of nationality. Any differences should encourage the emergence of a wise attitude, not the attitude that increasingly worsens the relationship, such as the current reaction to opinions of the MUI. ${ }^{64} \mathrm{With}$ the range of this awareness, Wahid hopes that Islam will be the great religion, along with the maturity of attitude and vastness view of the Muslims. ${ }^{65}$

As mentioned earlier, Wahid did not pen complete academic writings, systematically and comprehensively about his ideas of pluralism, humanism, and tolerance among religions. He focused more on giving examples of concrete action in fighting for and the realization of pluralism. During his presidential term for instance, Wahid, through Presidential Decree No. 6/2000, repealed regulations that prohibit Confucian adherents to practice their faith openly. Until that time, Indonesia only recognized five religions: Islam, Catholicism, Protestantism, Hinduism, and Buddhism. Wahid also overturned a decree of the Minister of the Interior in 1974 which required filling the column of religion on Identity Cards, because it was contrary to Article 29 UUD 1945 on Religious Freedom and

\footnotetext{
${ }^{62}$ Anwar, "Islamku", xvi. Ibid., 81.

${ }^{63}$ Wahid, "Lain Zaman", xxix.

${ }^{64}$ Ibid., xxvii.

65Ibid., xxviii.
} 
Human Rights. Since Wahid's tenure as President, while still only six religions are officially recognized, the law does not forbid other religions.

Wahid also suggested revoking TAP MPRS No. XXIX/MPR/1966 which prohibits Marxism-Leninism, but his proposal was stranded by massive rejection from diverse elements of society, especially from Muslims who were traumatized by the Indonesian Communist Party (PKI) movement and events surrounding 30 September 1965. All these efforts show Wahid's strong commitment to pluralism and universal humanism, which can no longer be limited by narrow primordial barriers.

\section{The indigenization of Islam}

As a clergy with a strong sense of culture, Wahid initiated the so-called "indigenization of Islam (pribumisasi Islam)." This term also deserves to be placed as one of the important elements of pluralism in Wahid. The thesis of indigenization for Wahid stems from the fact that Islam experienced major changes in its history. In the field of theology, jurisprudence, political and other elements of Islam, it has always had struggles and dialectic with cultures around the world. Wherever Islam came to and was welcomed the Islamic spirit remained in its essence, but its form (outer aspect) did not necessarily remain "Arabian," because there is no necessity (obligation) to uniform religious law. In the context of Indonesian Islam, Wahid asked: "why the word "shalat" should be used, if the Indonesian word "sembahyang" is no less true? Why should one say "mushala", whereas it was formerly langgar or surau? Not to mention the word "birthday," which feels just as "comfortable" when one uses the term "milad". Once tuan guru or kyai, do ustadz and sheikh titles now feel more authoritative? Have these Islamic signs not been deprived of the locality, which originally supported the presence of Islam in the archipelago? 60

According to Wahid, "indigenization" is a matter of the manifestation or expression of Islamic life, not the core doctrine

${ }^{66}$ Abdurrahman Wahid, "Salahkah Jika Dipribumikan?," in Melawan dengan Lelucon, ed. Ismail, 63-64. 
concerning faith and formal worship. Stressing that there is no need for a "Batak al-Qur'an", neither for a "Javanese Hadith" because Islam is Islam wherever it is, he said: "by no means, should all be equated by its outer-form." But, as a form of devotion to the culture that has long been rooted in the archipelago, Wahid rhetorically asked: "Is it wrong if "indigenization" of Islam be understood as the manifestation of life?" 67 Of course for Wahid, the answers was not merely that it was not wrong, but it was also necessary to show that Islam is "grace towards all the world" ("rahmah li al-älamin") where its grace can "touch" or "accommodate" human cultures in line with the essence of the teachings of Islam, and that grace can manifest itself even in the face of humanistic culture.

\section{Wahid and Depth Islam}

The records show that Wahid's ideas about pluralism, humanism, and tolerance are rooted in the historical heritage of Islamic civilization that is inclusive and cosmopolitan, as well as Pancasila and the true diversity of the culture of Indonesian society. Moreover, Wahid realized that he was also exploring the so-called "depth Islam." Depth Islam is not a literal and superficial form of Islam. Depth Islam is an understanding that goes beyond the literal texts to look for the principles and spirit of Islam in appreciating humanity, diversity, and peace. Depth Islam can also be referred to as "liberal Islam" or "substantial Islam," in terms of looking at the whole context of the text and beyond. Depth Islam is implicit in Wahid views of theology and culture about humanism, pluralism, and the indigenization Islam, as well as his opposition to the formalization and promotion of Islam as an ideology, which according to Wahid, will only bring new forms of discrimination, intolerance, and religious exclusivism. These being negative attitudes contrary to the spirit and principles of the humanist Islam, which want to develop life, the reality of diversity.

Depth Islam is also be understood through Wahid's writings of entitled Dialog Agama dan Masalab Pendangkalan Agama (1998) which cited concrete psychological and theological barriers in

67Ibid., 64. 
interfaith dialogue, especially for the Muslims. According to Wahid, in the 1990s the Indonesian Muslim religion was experiencing a process of silting due to its interaction with the model of Islamic Middle East which Islam as an ideology or a political commodity. ${ }^{68}$

There are two other important factors, in addition to the Middle East influence that affect the development of Islam in Indonesia. According to Wahid these are: firstly, many Muslims are living in a transition from traditional to modern life, which then results in the loss of psychological and cultural roots. Many people live in big modern cities, but are mentally still "tacky." They fear modernization will push into not being good believers. Due to this, their religious attitudes tend to be rigid, harsh and intolerant. Secondly, Islam has become an arena of political interests, where people are turned against each other for political gain. Accordingly, then appear a process silting of religion: where the interest of Islam is placed exclusively as the ultimate interest. Obviously, this situation led to religious exclusivism among Muslims. ${ }^{69}$

According to Wahid, who is close to non-Muslims, in some ways more than to other Muslims, he often received sharp criticism from Islamic leaders. In their critic, they often refer to verses of the Qur'an, where the Prophet Muhammad and his followers were hard against the unbelievers and polite to others (asyidda' 'alā al-kuffär, rubamà' baynahum). ${ }^{70}$ Wahid takes this criticism seriously, because they quote the Qur'an. He points out, that they have made a serious mistake because being "hard against the unbelievers" in the context of the verses, does not point to non-Muslims, but to the infidels (the polytheists of Mecca), who fought Islam.

Of course, there are differences between people with a nonMuslim infidels like that-let's say categorically infidels. Then, the "courtesy toward one another" (ruhamä, baynabum) is also

${ }^{68}$ Abdurrahman Wahid, "Dialog Agama dan Masalah Pendangkalan Agama," in Passing Over, Melintasi Batas Agama, ed. Komaruddin Hidayat and Ahmad Gaus (Jakarta: Gramedia, 1998), 51-52.

"9Ibid., 52.

70See Qs. al-Fath: 9. 
questionable. The Prophet Muhammad once said, "If my daughter Fatima steals, then will I cut her hands." Is it polite attitude Apostle or not? According to Wahid, was polite, because the Prophet loved Fatima and do not want her to do despicable acts. But that politeness may be shown by cutting off her hand, if she steals. Hence, the question: What is the measurement of closeness and politeness? Whether, if not a pleasant to one party is not considered polite to the Muslims? Hypothetically, for Wahid, the essence of "mutually sympathize" lays precisely in the correct mutual attitudes fellow Muslims. ${ }^{71}$

Another exclusive and anti-tolerant attitude which is often demonstrated by exclusive Muslims by quoting a favorite verse of "For, never will the the Jews be pleased with you, nor yet the Christians, unless you follow their own creed" (Qs. al-Baqarah: 120). ${ }^{72}$ According to Wahid, the word "never will be pleased" commonly regarded by Muslims as resistance or hostility towards Muslims, and was associated with the construction of churches, preaching the gospel, Christianization, the IsraeliPalestinian conflict, and others. Two entirely different things are placed in a relationship that is not clear. In fact for Wahid, if the problem was placed proportionally, Muslims will not misunderstand the meaning of "never will be pleased." 73

According to Wahid, the verse means that "they are will never be pleased to accept the basic concepts (of Islam)." In his explanation, Wahid told a parable about a young girl who was forced to marry an old man. She would certainly not do it willingly. That is, because she is unable to accept the basic concept that she will live happily, if she married the old man. Nevertheless, she is not necessarily hostile or against it. She would be forced to undergo marriage, though not willingly. Just like Siti Nurbaya was forced to marry Datuk Maringgih. ${ }^{74}$

The view that Jews and Christians cannot accept the basic concepts of Islam, for Wahid, is a given (a sure thing, which of course should be so), because, if they are willing to accept this, it

\footnotetext{
${ }^{71}$ Wahid, "Dialog", 53.

${ }^{72}$ See Asad, The Message, 25.

73Wahid, "Dialog", 53-54.

${ }^{74}$ Ibid., 54.
} 
means they are no longer Jews and Christians. It works the same way for the opposite side. Muslims would not be willing to basic concepts of Judaism and Christianity. If one takes the concept of divinity in Christianity, a Muslim would have difficulty accepting it because it conceptually differs to that of Islam. However, this does not necessarily mean one must show hatred and hostility. ${ }^{75}$ In Islam, a Muslim must be steadfast in his or her belief, but at the same time he/she must also be willing to listen to and respect other people's beliefs and opinions.

Wahid is a unique Indonesian Muslim. In the sense that he dares to break through the thick wall of exclusiveness and conservatism espoused largely by the Muslims of Indonesia. The fact that he hails from the nobility or very elite of his respective tradition, has not made him takes an advantage of his high social status and live luxuriously. Instead, he uses his position to fight for equality, peace and justice to mankind. He has dedicated his entire live to those three things.

Owing to that, Wahid has not only made a large contribution to give a face to inclusive Indonesian Islam, but has also become the face of Islamic Southeast Asia, where he is known and well-remembered by Islamic leaders of Malaysia, Singapore, Brunei, Thailand, and the Philippines. In Indonesia alone, in addition to hundreds of books and articles written about Wahid, there have appeared thousands of young Muslims who are continuing to develop Wahid ideas of universal Islam, inclusivity and pluralism. They have formed a network of thinkers and NGOs, such as the Liberal Islam Network, the Moderate Muslim Network, the Neo-Traditionalism group, and Gusdurian forum. In 2004, the Wahid Family and their sympathizers founded The Wahid Institute, an organization that seeks to realize the principles and ideals of Abdurrahman Wahid's in building moderate Islamic intellectual thought, which encourages the creation of democracy, multiculturalism and tolerance among Muslims in Indonesia and around the world.

Wahid began his career as a teacher of religion, and engages fully in schools and community development activities through NGOs. He is a genuine social activist, he spent his life working

${ }^{75}$ Ibid. 
with Muslim communities. His activities delivered him to be chairman of NU for two periods. He eventually became the fourth President of Indonesia for 22 months. With political power in his hands, Wahid succeeded in realizing his ideas on political pluralism in the form of regulation.

\section{Conclusion}

No doubt, Wahid is an inclusivist, but he is a pluralist: epistemological and mystical pluralist. Eventually, the whole life and works of Wahid showed that he was a humanist-universalist par excellent. Wahid's depth-Islam may has arisen because of the long process of religious internalization within Wahid himself, but it is also a hybrid form, i.e., it is a result of the process of encountering or learning his own tradition inter-mingling with cultures of the wider world. In contrast to depth-Islam, the introduction of what may be called "instant religion" and the tendency to ideologize has filled Indonesia--in these bustling days--with religious groups that are intolerant and exclusive. The situation is ironic, because Indonesia is actually rich with cultural and diverse religious thoughts, and was for centuries "considered" as a peaceful and tolerant country.

\section{References}

Ali, Muhammad, "Wahid as a Defender of Pluralism and Religious Freedom," The Jakarta Post, January 6, 2010.

Ali, Muhammad, "Wahid as a Defender of Pluralism", The Jakarta Post, January 6, 2010. Republished by the Wahid Institute http://wahidinstitute.org/v1/Opinion/Detail/ $? \mathrm{id}=244 / \mathrm{hl}=$ en/Gus_D ur_As_A_Defender_Of_Pluralism_Religious_Freedom

Asad, Muhammad, The Message of The Qur'an. Gibraltar: Dar al-Andalus, $15^{\text {th Hijriyya. }}$

Austin, RWJ, Sufis of Andalusia. London: George Allen \&Unwin, 1971.

Barton, Greg, Gus Dur: The Authorized Biography of Abdurrabman Wabid. Jakarta-Singapore: Equinox Publishing, 2002.

Basyaib, Hamid and Fajar Hermawan (eds.), Ger-Geran Bersama Gus Dur: Edisi Spesial Mengenang Gus Dur. Jakarta: Penerbit Nawas, 2010.

Brill, Alan. Judaism and Other Religions: Models of Understanding. New York, USA: Palgrave MacMillan, 2010.

Fuad, Zainul, Religious Pluralism in Indonesia: Muslim-Christian Discourse. Hamburg: Hamburg University, 2007. 
Isre, Moh. Shaleh (ed.), Tabayun Gus Dur, Pribumisasi Islam, Hak Minoritas, Reformasi Kultural. Yogyakarta: LKIS, 1998.

Knitter, Paul F. Introducing Theologies of Religions. New York: Orbis Books, 2003.

Knitter, Paul F. No Other Names? A Critical Survey of Christian Attitudes toward the World Religions. New York: Orbis Books, 1985.

Knitter, Paul F. One Earth Many Religions: Multifaith Dialogue and Global Responsibility. New York: Orbis Books, 1985.

Knitter, Paul F. The Myth of Religious Superiority: Multifaith Explorations of Religious Pluralism. New York: Orbis Books, 2005.

Lyden, John (ed.). Enduring Issues in Religion. San Diego, USA: Greenhaven Press, 1995.

Martahan Sitompul, Einar, NU dan Pancasila: Sejarab dan Peranan NU dalam Perjuangan Umat Islam di Indonesia dalam rangka Penerimaan Pancasila sebagai Satu-Satunya Asas. Jakarta: Sinar Harapan, 1989.

Muhammad, Husein, "Pluralisme Wahid, Gagasan Para Sufi," Cahaya Sufi, 61 (2010): 102-103.

Nahrowi, Agus Hadi, "Religious Pluralism In Indonesia: Helpful and Hindering Aspects," Issuelab, August, 10 (2006): 1-27. http:/ / www.issuelab.org/organizations/profile/pluralism_project

Nasr, Seyyed Hossein. Knowledge and the Sacred. Albany, New York: State University of New York Press, 1989.

Riyadi, Hendar. Melampaui Pluralisme: Etika al-Quran tentang Keragaman Agama. Jakarta: RMBooks\& PSAP, 2007.

Wahid, Abdurrahman, "Beberapa Aspek Teoritis dari Pemikiran Politik dan Negara Islam,” Aula, no. 1 (1987): 45-48.

. "Dialog Agama dan Masalah Pendangkalan Agama," in Passing Over, Melintasi Batas Agama, ed. Komaruddin Hidayat and Ahmad Gaus (51-52). Jakarta: Gramedia, 1998.

. "Dicari: Keunggulan Budaya," Duta Masyarakat, July 5, 2003.

2011.

. "Harlah, Natal, dan Maulid," www.gusdur.net, December 23,

- "Haruskah Inul Diberangus?" Memorandum, May 10, 2003. Republished at http://pemikirangusdur.blogspot.co.id/2015/01/ haruskah-inul-diberangus.html

. "Kebenaran dan Penolakan Atasnya." In Kala Fatwa Jadi Penjara, edited by Ahmad Suaedy (120-121). Jakarta: The Wahid Institute, 2006.

-------. "Lain Zaman, Lain Pendekatan." In Kala Fatwa Jadi Penjara, edited by Ahmad Suaedy (15-18). Jakarta: The Wahid Institute, 2006.

. "Peranan Umat dalam Berbagai Pendekatan." In Kontroversi Pemikiran Islam di Indonesia, edited by LPPM (199-201). Bandung: Remaja Rosdakarya, 1990.

1999. 
. "Universalisme Islam dan Kosmopolitanisme Peradaban Islam."

In Kontekstualisasi Doktrin Islam dalam Sejarah, edited by Budhy Munawar-Rachman (545-550). Jakarta: Yayasan Paramadina, 1995.

-----. Islamku, Islam Anda, Islam Kita: Agama Masyarakat Negara

Demokrasi. Jakarta: The Wahid Institute, 2006.

. Muslim di Tengah Pergumulan. Jakarta: Leppenas, 1981.

--------. "Kasidah." In Melawan dengan Lelucon: Kumpulan Kolom Abdurrahman Wabid di Tempo, edited by Mustafa Ismail, 249-50. Jakarta: Tempo, 2000.

Wahid, Inayah, "Wahid Bukan Tokoh Pluralisme," Tribunnews October 16, 2012.http://www.issuelab.org/organizations/profile/pluralism_project 
328 Ulumuna, Vol. 19, No. 2 (Dec) 2015 